\title{
Kesan Triali Isosianurat (TIAC) Terhadap Sifat Tegangan Filem Poly L-Laktid Asid (PLLA) yang Diiradiasi Gamma dan Alur Elektron
}

(The Effect of Trially Isocyanurate (TIAC) on the Tensile Property of Poly L-Lactide Acid (PLLA) Film Irradiated under Gamma and Electron Beam)

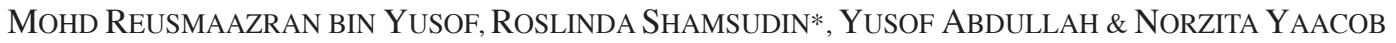

\begin{abstract}
ABSTRAK
PLLA merupakan biodegrasi polimer yang mempunyai aplikasi yang meluas dalam pelbagai bidang industri dan perubatan. Dalam kajian ini, PLLA telah dicampurkan dengan triali isosianurat (TIAC) antara 1 hingga $6 \mathrm{v} / \mathrm{v} \%$ bagi melihat perubahan sifat tegangan dan terikan filem PLLA. TIAC biasanya digunakan sebagai agen taut silang dan keplastikan untuk mengubah sifat polimer. Campuran PLLA-TIAC telah diiradiasi pada $10 \mathrm{kGy}$ di bawah alur elektron (EB) dan gamma $(\gamma)$. Keputusan menunjukkan kekuatan tegangan (tegasan maksimum) menurun dengan peningkatan kandungan TIAC di dalam PLLA tetapi meningkat sedikit pada 4 v/v\% TIAC bagi PLLA iradiasi dan tanpa iradiasi. Manakala nilai terikan didapati meningkat pada TIAC $2 \mathrm{v} / \mathrm{v} \%$ dan menurun apabila TIAC ditambah melebihi $2 \% \mathrm{v} / \mathrm{v} \%$ terutamanya bagi PLLA yang diiradiasikan. Daripada keputusan DSC terdapat perubahan pada suhu peralihan kaca, $T_{g}$, suhu penghabluran sejuk, $T$, entalpi penghabluran sejuk, $H_{c}$ dan suhu peleburan, $T_{m}$ menunjukkan berlaku perubahan pergerakan rantaian PLLA dan fasa penghabluran dengan kehadiran TIAC dan sinaran mengion di dalam PLLA. Perubahan pada puncak penyerapan spektra infra merah jelmaan fourier (FTIR) menunjukkan berlaku penggantian atau kemasukkan molekul TIAC ke dalam rantian PLLA.
\end{abstract}

Kata kunci: Iradiasi elektron; iradiasi gamma; kekuatan tegangan; PLLA; TIAC

\section{ABSTRACT}

PLLA is a biodegradable polymer that is widely used in industrial and medical field. In this works, PLLA was mixed with 1-6 v/v\% with (TIAC) to investigate the changes in tensile and strains properties of the PLLA film. PLLA commonly used as plasticizer or crosslinked agent to change the polymer property. PLLA and TIAC mixture was irradiated under $10 \mathrm{kGy}$ doses for both of gamma $(\gamma)$ and electron beam (EB). The results showed that the tensile strength (maximum stress) reduce with the increasing of TIAC amount in the PLLA but slightly increase at $4 \mathrm{v} / \mathrm{v} \%$ TIAC addition for both irradiated and non-irradiated PLLA. Strain was found to increase at $2 v / v \%$. TIAC but decreased when more than 2 v/v\% TIAC was added for irradiated PLLA. DSC results showed the changes in glass transition temperature, $T_{g}$, cold crystallization enthalpy, $H_{c}$, cold crystallization temperature, $T_{c}$ and melting temperature, $T_{m}$ indicate the changes in mobility of PLLA chain and crystallization regions with present of TIAC and ionizing radiation in PLLA. The changes in fourier transform infra-red (FTIR) absorptions peak indicate the penetrating of TIAC molecules into the PLLA chains.

Keywords: Electron beam irradiation; gamma irradiation; PLLA; tensile strength; TIAC

\section{PENGENALAN}

PLLA merupakan polimer biodegradasi, bioserasi dan tidak toksid yang boleh dihasilkan daripada sumber diperbaharui. PLLA kini semakin menarik perhatian penyelidik kerana berpotensi sebagai bahan alternatif bagi menggantikan polimer sintetik samada dari sudut perubatan (Lou et al. 2014; Rodenas-Rochina et al. 2015), industri (Mat Uzir et al. 2015; Nur Aimi et al. 2015) dan alam sekitar (Quynh et al. 2007). Walau bagaimanapun, PLLA sering dikaitkan dengan kelemahan pada sifat mekanik dan sifat terma walaupun menunjukkan prestasi yang begitu cemerlang dalam sifat kebioserasian. Kejayaan PLLA dalam aplikasi implan perubatan menyebabkan PLLA semakin menarik untuk dimodifikasikan bagi meningkatkan sifat-sifat PLLA (Eftekhari et al. 2014; Milicevic et al. 2010; Zhang et al. 2010). Proses penyinaran atau iradiasi menggunakan sinaran mengion seperti elektron, gamma $(\gamma)$ dan juga neutron merupakan kaedah yang diguna pakai bagi meningkatkan sifat PLLA dengan sinaran mengion mampu mengubah sifat mekanik dan degradasi PLLA melalui taut silang atau degradasi rantaian polimer PLLA. Penggunaan sinar $\gamma$ dilihat lebih banyak digunakan oleh kebanyakan penyelidik kerana mempunyai tenaga yang tinggi dan kadar penembusan yang lebih baik bagi menghasilkan radikal-radikal bebas untuk bertindak balas dengan rantaian polimer (Liu et al. 2012; Milicevic et al. 2012, 2010; Said 2013). Manakala sinaran elektron mempunyai tenaga permulaan yang tinggi dan pemindahan tenaga adalah melalui pelanggaran elektron pada petala paling luar atom. Sinaran elektron mempunyai jarak penembusan yang 
lebih rendah berbanding dengan sinaran $\gamma$ dan beberapa penyelidik turut menggunakan kaedah ini untuk mengubah sifat PLLA (Raghu et al. 2016; Zhang et al. 2010).

Penggunaan agen taut silang dan keplastikan juga mampu mengubah sifat mekanik PLLA dan polimer lain seperti trimetilolpropana triakralat (TMPTA), trimetalil sianurat (TMAIC), triali isosianurat (TAIC), dibenzoil peroksida (DBP) dan dikumil peroksida (DCP). Penggunaan TIAC bersama dengan komposit asid poli-laktid dan poli(etelena-co-vinil alkohol) dan disinarkan pada pelbagai dos sinaran elektron telah menunjukkan peningkatan kekuatan tegangan pada dos yang lebih rendah (Liu et al. 2012). Manakala perbandingan antara dua jenis agen taut silang iaitu TMPTA dan TIAC pernah dilakukan oleh Rytlewski et. al. (2010) dan diiradiasikan sehingga $100 \mathrm{kGy}$ dibawah alur elektron. Beliau mendapati TMPTA menggalakkan degradasi berbanding TIAC yang menggalakkan taut silang walaupun pada dos sinaran yang tinggi. TIAC merupakan sebatian pelbagai fungsi yang akan bersifat sebagai agen keplastikan tanpa kehadiran sinaran mengion. Dengan kehadiran sinaran mengion TIAC boleh bertindak sebagai agen taut silang pada dos sinaran yang sesuai bergantung kepada berat molekul PLLA yang digunakan. PLLA dengan kehadiran TIAC dibawah sinaran mengion kemungkinan akan membentuk 2 fasa iaitu taut silang dan degradasi. Ianya terhasil daripada pembentukan struktur radikal yang berbeza-beza yang akan menyebabkan tindak-balas radiasi seperti pencantuman semula dan pemutusan ikatan. Keberkesanan TIAC di dalam PLLA terhadap jenis sinaran mengion masih kurang dibincangkan secara perbandingan pada sifat kekuatan PLLA. Oleh itu kajian ini dijalankan bertujuan untuk melihat kesan kandungan TIAC yang pelbagai terhadap PLLA dibawah pengaruh dua jenis sinaran mengion gamma dan elektron pada julat dos yang ditetapkan.

\section{BAHAN DAN KAEDAH}

PLLA dengan kelikatan terwujud $2.321 \mathrm{dL} \mathrm{g}^{-1}$ diperoleh daripada BioInvigor (Taipe, Taiwan) dan TIAC diperoleh secara komersil daripada Sigma Adrich(Germany) manakala diklorometana (LEDA, gred HPLC, Sepanyol) digunakan sebagai pelarut kepada PLLA. Filem PLLA disediakan melalui kaedah pemeluwapan tuangan dengan larutan PLLA disediakan dengan melarutkan granul PLLA di dalam diklorometana pada kepekatan 7 v/v\%. Kemudian TIAC dicampurkan pada campuran 1, 2, 4 dan $6 \mathrm{v} / \mathrm{v} \%$ daripada larutan PLLA dan dikacau selama 24 jam. Campuran ditarik di atas kepingan kaca dengan penggulung $200 \mu \mathrm{m}$ dan dikeringkan selama 24 jam. Filem PLLA berketebalan 0.009 hingga $0.013 \mathrm{~mm}$ diperoleh selepas pengeringan.

Penyinaran atau iradiasi filem PLLA/TIAC dilakukan di Loji Penyinaran Gamma, Agensi Nuklear Malaysia pada dos penyerapan $10 \mathrm{kGy}$ dengan kadar $1.67 \mathrm{kGyh}^{-1}$ dan ${ }^{60}$ Co sebagai punca sinaran. Bagi iradiasi elektron, iradiasi dilakukan pada dos penyerapan $10 \mathrm{kGy}$ di Loji
Alur Elektron dengan punca tenaga $20 \mathrm{keV}$ pada arus 2 mA dan kadar dos sinaran $5 \mathrm{kGy}$ bagi setiap laluan iradiasi bagi mengurangkan kesan haba iradiasi.

Ujian tegangan dilakukan dengan menggunakan mesin ujian universal (Instron, 8874, UK) pada $50 \mathrm{~N}$ sel bebanan dengan kelajuan $0.5 \mathrm{~mm} / \mathrm{min}$ bagi memperolehi lengkung tegasan-terikan.

Perubahan sifat terma, suhu peralihan kaca, $T_{g}$, suhu penghabluran sejuk, $\mathrm{T}_{\mathrm{c}}$ dan entalpi penghabluran diperoleh daripada kalorimetri imbasan pembeza, DSC (TA Instrument, Q20, USA). Sampel dialirkan dengan gas nitrogen pada kadar $35 \mathrm{mLmin}^{-1}$ untuk mengelakkan pengoksidaan semasa pemanasan. Sampel seberat 4-5 mg dipanaskan daripada 20 hingga $300^{\circ} \mathrm{C}$ pada kadar $10^{\circ} \mathrm{C} \mathrm{min}^{-1}$. Hanya PLLA tanpa TIAC dan dengan kandungan TIAC 1 dan $6 \mathrm{v} / \mathrm{v} \%$ dilakukan ujian terma DSC bagi melihat perubahan sifat terma terhadap perubahan kandungan TIAC.

Interaksi kimia bagi PLLA/TIAC diukur menggunakan spektra infra merah jelmaan fourier, FTIR (Perkin Elmer, USA) bagi filem sebelum dan selepas iradiasi. Spektra dirakam pada julat $400-4000 \mathrm{~cm}^{-1}$ dengan bilangan imbasan sebanyak 16 kali.

\section{HASIL DAN PERBINCANGAN}

Secara umumnya kekuatan tegangan menurun dengan peningkatan kandungan TIAC di dalam PLLA tetapi meningkatkan sifat terikan PLLA pada kandungan TIAC yang rendah. Penurunan kekuatan tegangan ini berlaku disebabkan oleh kesan larutan molekul TIAC yang tidak bertindak balas dengan rantaian PLLA. Molekul TIAC akan memasuki ruang rantaian antara molekul PLLA dan melemahkan daya antara molekul PLLA dan menyebabkan rantaian PLLA akan lebih senang bergerak (Malinowski et al. 2015). Rajah 1(a) menunjukkan kekuatan tegangan PLLA dengan perubahan kandungan TIAC bagi sampel yang diradiasi dan tanpa iradiasi. PLLA tidak diiradiasi dan tanpa TIAC menunjukkan kekuatan yang rendah berbanding dengan PLLA yang diiradiasikan. Sampel PLLA tanpa TIAC, menunjukkan peningkatan kekuatan tegangan sehingga 26\% iaitu daripada 43.10 kepada $54.54 \mathrm{MPa}$ (Jadual 1) apabila diiradiasikan oleh $\gamma$. Manakala sampel yang iradiasi menggunakan sinaran elektron, kekuatan tegangan meningkat sebanyak 7\% iaitu meningkat kepada 46.87 $\mathrm{MPa}$. Ini berkemungkinan disebabkan berlaku taut silang pada rantaian PLLA pada dos $10 \mathrm{kGy}$. PLLA diiradiasikan $\gamma$ menunjukkan kekuatan tegangan yang lebih tinggi berbanding dengan alur elektron disebabkan sinar gamma mempunyai kadar penembusan yang lebih tinggi dan menghasilkan kesan taut silang yang lebih baik (Nagasawa et al. 2005).

Pada kandungan TIAC $1 \mathrm{v} / \mathrm{v} \%$, PLLA yang diiradiasi dengan alur elektron menunjukkan peningkatan kekuatan tegangan sebanyak 27\% MPa iaitu daripada 42.09 kepada 53.57 MPa dengan kehadiran TIAC pada kandungan yang rendah ( $1 \mathrm{v} / \mathrm{v} \%)$ membantu taut silang bagi PLLA. Penurunan kekuatan tegangan yang ketara didapati berlaku 
apabila campuran $2 \mathrm{v} / \mathrm{v} \%$ iaitu sekitar 47 hingga $59 \% \mathrm{MPa}$ bagi PLLA tanpa iradiasi dan diiradiasi. Pada campuran ini juga PLLA menunjukkan peningkatan ketara pada terikan (Rajah 1(b)). Ini menunjukan peningkatan TIAC menyebabkan lebih banyak molekul TIAC memasuki ruang antara molekul PLLA atau berlakunya sambungan linear pada hujung rantaian makromolekul PLLA (Malinowski 2016). Ini menyebabkan berlaku peningkatan pemanjangan PLLA dan menurunkan kekuatan tegangan PLLA (Rajah 1(b)) dengan TIAC dilihat mampu meningkatkan fasa keplastikan pada PLLA. Kekuatan tegangan menunjukkan sedikit peningkatan pada kandungan 4 v/v\% TIAC dan menunjukkan berlaku taut silang antara rantain PLLA dan TIAC. Bagi PLLA yang diiradisi kekuatan tegangan dilihat lebih rendah berbanding dengan PLLA tidak diiradiasikan. Ini menunujukkan pemutusan rangkaian antara molekul turut berlaku menyebabkan PLLA yang diiradiasi menunjukkan penurunan ketara pada terikan PLLA. Pada campuran 4 v/v\% TIAC kekuatan tegangan meningkat antara $34 \%$ dan $38 \% \mathrm{MPa}$ masing-masing bagi PLLA tidak diiradiasi dan PLLA yang diiradiasi dengan elektron. PLLA yang diiradiasi menggunakan $\gamma$ tidak menunjukkan sebarang perubahan pada kekuatan tegangan. Kekuatan tegangan PLLA yang diiradiasi adalah lebih rendah disebabkan kemungkinan sebahagian rantaian molekul turut berlaku degradasi (Loo et al. 2004; Suljovrujić et al. 2007). Keadaan ini dinamakan degradasi teraruh iradiasi (radiation induced degradation). Ini dapat dilihat apabila berlaku penurunan ketara pada terikan bagi PLLA yang diiradiasi (Rajah 1(b)). Pada kandungan yang lebih tinggi iaitu $6 \mathrm{v} / \mathrm{v} \%$ kesan TIAC keatas sifat keplastikan telah berkurangan menyebabkan penurunan kekuatan tegangan dan terikan. Peningkatan nilai terikan ketara pada campuran TIAC $1-2 \mathrm{v} / \mathrm{v} \%$ dan terikan didapati malar bagi pada kandungan TIAC yang lebih tinggi bagi PLLA yang tidak diiradiasi. Manakala terikan dipadati menurun bagi PLLA yang diiradiasi dengan kedua sumber sinaran mengion tersebut (Rajah 2 dan Jadual 2). Menurut Nagasawa et al. (2005) bahawa kandungan TIAC yang sesuai adalah sekitar 3-4 v/v\% kerana pada peratusan kandungan tersebut ia mempunyai radikal bebas yang mencukupi untuk bertindak balas dengan rantian PLLA. Sebagai perbandingan, nilai kekuatan dan terikan PLLA/
TIAC dan PLLA tanpa TIAC bagi kedua-dua jenis sinaran mengion ( $\gamma$ dan elektron) juga ditunjukkan di dalam Jadual 1 dan 2.

Pengunaan TIAC di dalam PLLA yang tidak diiradiasi menyebabkan penurunan suhu peralihan kaca $\mathrm{T}_{\mathrm{g}}$ sebagai mana yang ditunjukkan oleh Rajah 2(a), $\mathrm{T}_{\mathrm{g}}$ berubah dari 67.5 kepada $59.5^{\circ} \mathrm{C}$ bagi kandungan $1 \mathrm{v} / \mathrm{v} \%$ TIAC dan $\mathrm{Tg}$
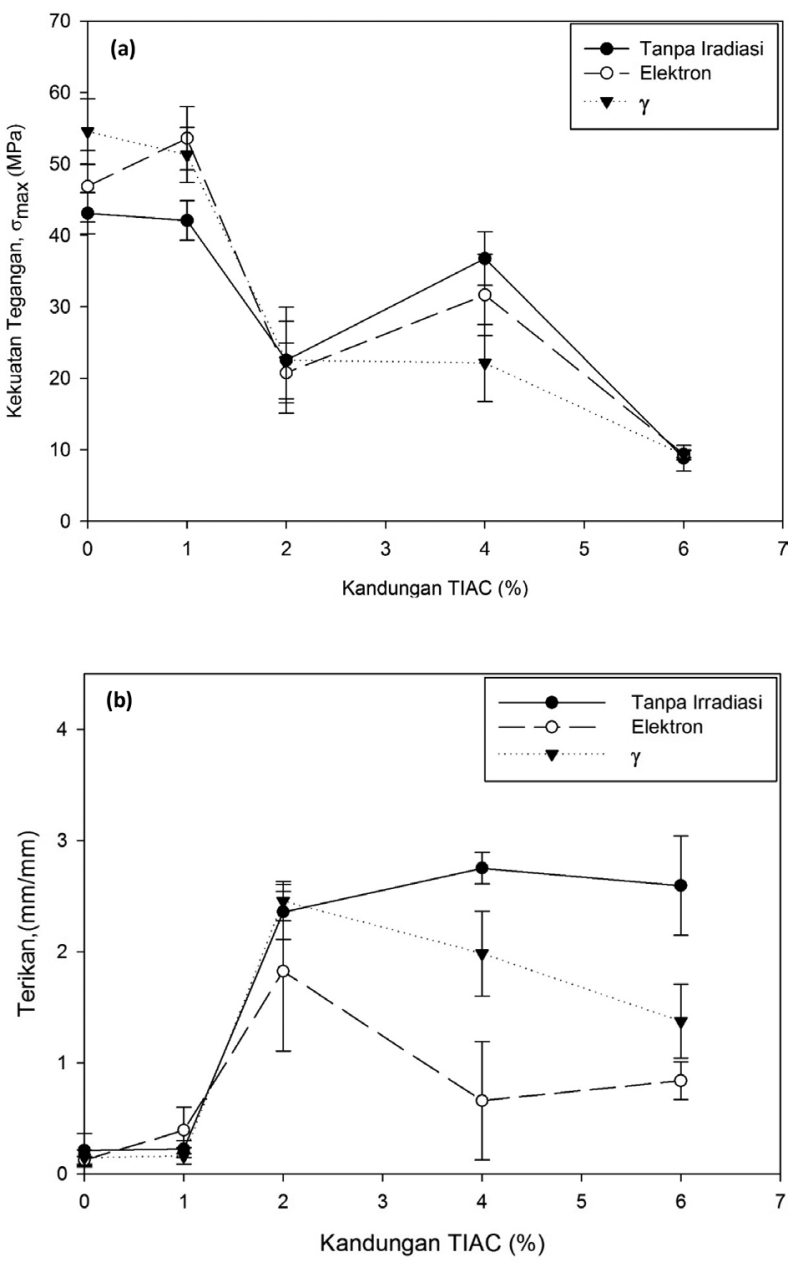

RAJAH 1. Lengkung perubahan (a) kekuatan tegangan dan (b) terikan PLLA terhadap kandungan TIAC bagi sampel yang diiradiasi dan tidak diiradiasi

JADUAL 1. Jadual menunjukkan nilai tegangan terhadap perubahan kandungan TIAC di bawah sinaran $\gamma$ dan elektron

\begin{tabular}{cccc}
\hline \multirow{2}{*}{$\%$ TIAC $(\mathrm{v} / \mathrm{v})$} & \multicolumn{3}{c}{ Kekuatan tegangan, $\sigma_{\max }(\mathrm{MPa})$} \\
\cline { 2 - 4 } & Tanpa iradiasi & Elektron & $\gamma$ \\
\hline 0 & $43.10[2.879]$ & $46.87[4.974]$ & $54.54[4.585]$ \\
1 & $42.09[2.752]$ & $53.57[4.406]$ & $51.25[3.831]$ \\
2 & $22.53[7.421]$ & $20.76[4.183]$ & $22.54[5.430]$ \\
4 & $36.75[3.737]$ & $31.65[5.704]$ & $22.13[5.388]$ \\
6 & $8.81[1.785]$ & $9.377[0.491]$ & $9.30[0.692]$ \\
\hline
\end{tabular}

Sisihan piawaian, SD ditunjukkan di dalam kurungan[ ] 
JADUAL 2. Jadual menunjukkan nilai terikan terhadap perubahan kandungan TIAC di bawah sinaran $\gamma$ dan elektron

\begin{tabular}{ccccccc}
\hline \multirow{2}{*}{$\%$ TIAC $(\mathrm{v} / \mathrm{v})$} & \multicolumn{5}{c}{ Terikan, $\varepsilon(\mathrm{mm} / \mathrm{mm})$} \\
\cline { 2 - 7 } & \multicolumn{2}{c}{ Tanpa iradiasi } & \multicolumn{2}{c}{ Elektron } & \multicolumn{2}{c}{$\gamma$} \\
\hline 0 & 0.2128 & {$[0.1501]$} & 0.1230 & {$[0.0345]$} & 0.1458 & {$[0.0697]$} \\
1 & 0.2245 & {$[0.0755]$} & 0.3921 & {$[0.2092]$} & 0.1613 & {$[0.0747]$} \\
2 & 2.3569 & {$[0.2494]$} & 1.8231 & {$[0.7200]$} & 2.4542 & {$[0.1778]$} \\
4 & 2.7503 & {$[0.1405]$} & 0.6586 & {$[0.5323]$} & 1.9836 & {$[0.3825]$} \\
6 & 2.5942 & {$[0.4483]$} & 0.8376 & {$[0.1688]$} & 1.3725 & {$[0.3335]$} \\
\hline
\end{tabular}

Sisihan piawaian, SD ditunjukkan di dalam kurungun [ ]

berubah daripada 67.4 kepada $52.2^{\circ} \mathrm{C}$ bagi PLLA/TIAC yang diiradiasi dengan elektron dan 68.5 kepada $59.5^{\circ} \mathrm{C}$ bagi PLLA/TIAC yang yang diiradiasi dengan $\gamma$. Ini menunjukkan terdapat molekul TIAC telah bertindak balas dengan rantaian polimer PLLA walaupun pada kandungan yang rendah manakala pada kandungan TIAC yang lebih tinggi, $6 \mathrm{v} / \mathrm{v} \%$, tiada suhu peralihan kaca yang diperoleh. Bagi PLLA/TIAC yang tidak diiradiasi dan yang diiradiasikan. Pada kandungan ini ( $6 \mathrm{v} / \mathrm{v} \%$,) PLLA tidak bersifat peralihan daripada bersifat keras dan kekacaan kepada lembut dan anjal disebabkan rantai PLLA telah membentuk satu rantai panjang dengan molekul TIAC yang lebih menunjukkan sifat keplastikan. Ini menyebabkan tiada nila Tg diperoleh pada kandungan TIAC $6 \mathrm{v} / \mathrm{v} \%$ dengan elektron dan $\gamma$ juga menunjukkan penurunan nilai $\mathrm{T}_{\mathrm{g}}$ dengan penambahan kandungan TIAC $1 \mathrm{v} / \mathrm{v} \%$ (Rajah 2(b) dan 2(c)). Rajah 2(a) menunjukkan entalpi penghabluran sejuk, $\mathrm{H}_{\mathrm{c}}$ meningkat dengan peningkatan kandungan TIAC bagi PLLA yang tidak diiradiasikan. Ini menunjukkan pembentukan sistem fasa hetero apabila berlaku pencampuran antara TIAC dan PLLA (Rytlewski et al. 2010). Walau bagaimanapun, bagi PLLA yang mengandungi TIAC yang diiradiasi, menunjukkan penurunan entalpi penghabluran sejuk mungkin disebabkan oleh radiasi yang mengaruh kepada degradasi dan kesan TIAC yang memasuki ruang molekul-makro mencacatkan sifat kehabluran PLLA apabila diiradiasi (Loo et al. 2012). Bagi sampel tanpa TIAC (Rajah 2(a), (b) dan (c)) entalpi penghabluran sejuk meningkat dari $22.6 \mathrm{Jg}^{-1}$ bagi PLLA tidak diiradiasi kepada 38.6 dan $39.8 \mathrm{Jg}^{-1}$ bagi PLLA diiradiasi elektron dan $\gamma$. Keadaan ini disebabkan keperluan tenaga yang makin tinggi bagi PLLA yang diiradiasikan untuk menyusun rantaian secara lebih tersusun apabila dipanaskan. Ini menunjukkan berlakunya taut silang pada dos 10 kGy bagi PLLA tanpa kehadiran TIAC. Keadaan ini akan membantu meningkatkan kekuatan tegangan PLLA (Rajah 1(a)). Pada kandungan TIAC 6 v/v\% termogran DSC tidak menunjukkan sebarang nilai $\mathrm{T}_{\mathrm{g}}$ dan $\mathrm{T}_{\mathrm{c}}$ dan ia menunjukkan tidak berlaku penyusunan hablur (tiada kehadiran fasa hablur) kecuali PLLA yang diiradiasi oleh elektron. Nilai entalpi penghabluran yang rendah menunjukkan hanya sedikit penyusunan hablur yang berlaku semasa pemanasan.

Rajah 3 menunjukkan spektra FTIR, campuran dicirikan oleh puncak $1697 \mathrm{~cm}^{-1}$ bagi kumpulan sianurat pada TIAC (Liu et al. 2012) dan $1764 \mathrm{~cm}^{-1}$ bagi kumpulan karbonil pada PLLA. Kemunculan puncak baru pada $1649 \mathrm{~cm}^{-1}$ dicadangkan adalah daripada jaringan yang terbentuk antara molekul TIAC dan PLLA (Yang et al. 2008). Ikatan dubel pada TIAC lebih senang diputuskan untuk menghasilkan monomer untuk bertindak balas dengan molekul PLLA apabila percampuran berlaku. Jika dibandingkan puncak karbonil, $1764 \mathrm{~cm}^{-1}(\mathrm{C}=0)$ pada PLLA yang diiradiasi dan yang tidak diiradiasi ianya menunjukkan perubahan dan keamatan pada puncak. Perubahan keamatan dan kelebaran puncak ini menunjukkan bagaimana TIAC memasuki jaringan rantaian PLLA apabila menerima tenaga daripada sinaran mengion. Kelebaran puncak agak ketara dengan peningkatan kandungan TIAC namun keamatan pada kandungan $2 \mathrm{v} / \mathrm{v} \%$ adalah paling tinggi dan berlaku peningkatan mendadak pada terikan PLLA untuk kesemua komposisi. Menurut Yang et al. (2008) peningkatan pada jalur penyerapan menunjukkan berlakunya tindak balas kimia pada rantai PLLA. Bagi PLLA yang diiradiasi $\gamma$ keamatan dan kelebaran puncak sianurat pada $1697 \mathrm{~cm}^{-1}$ disebabkan oleh tenaga tuju sinar gamma adalah tinggi dan memberi tenaga yang mencukupi bagi perubahan ikatan dalam PLLA dan ini memberi ruang bagi molekul TIAC memasuki rantian PLLA (Rajah 3(c)).

\section{KESIMPULAN}

Penggunaan TIAC membantu meningkatkan sifat keplastikan PLLA tetapi akan merendahkan kekuatan tegangan PLLA. Perubahan ketara kekuatan tegangan dan terikan adalah pada kandungan TIAC yang lebih rendah (2\% $\mathrm{v} / \mathrm{v} \%)$. Manakala penggunaan sinaran mengion elektron dan gamma membantu meningkatkan kekuatan tegangan pada PLLA tanpa TIAC pada dos $10 \mathrm{kGy}$. Manakala degradasi didapati mendominasi rantaian PLLA/TIAC di bawah sinaran mengion dapat dilihat daripada sifat terma berdasarkan penyusunan kristal semasa memanasan dilakukan.

\section{RUJUKAN}

Eftekhari, S., El Sawi, I., Bagheri, Z.S., Turcotte, G. \& Bougherara, H. 2014. Fabrication and characterization of novel biomimetic PLLA/cellulose/hydroxyapatite nanocomposite for bone repair applications. Materials Science and Engineering C 39: 120-125.

Liu, M., Yin, Y., Fan, Z., Zheng, X., Shen, S., Deng, P., Zheng, C., Teng, H. \& Zhang, W. 2012. The effects of gamma-irradiation 

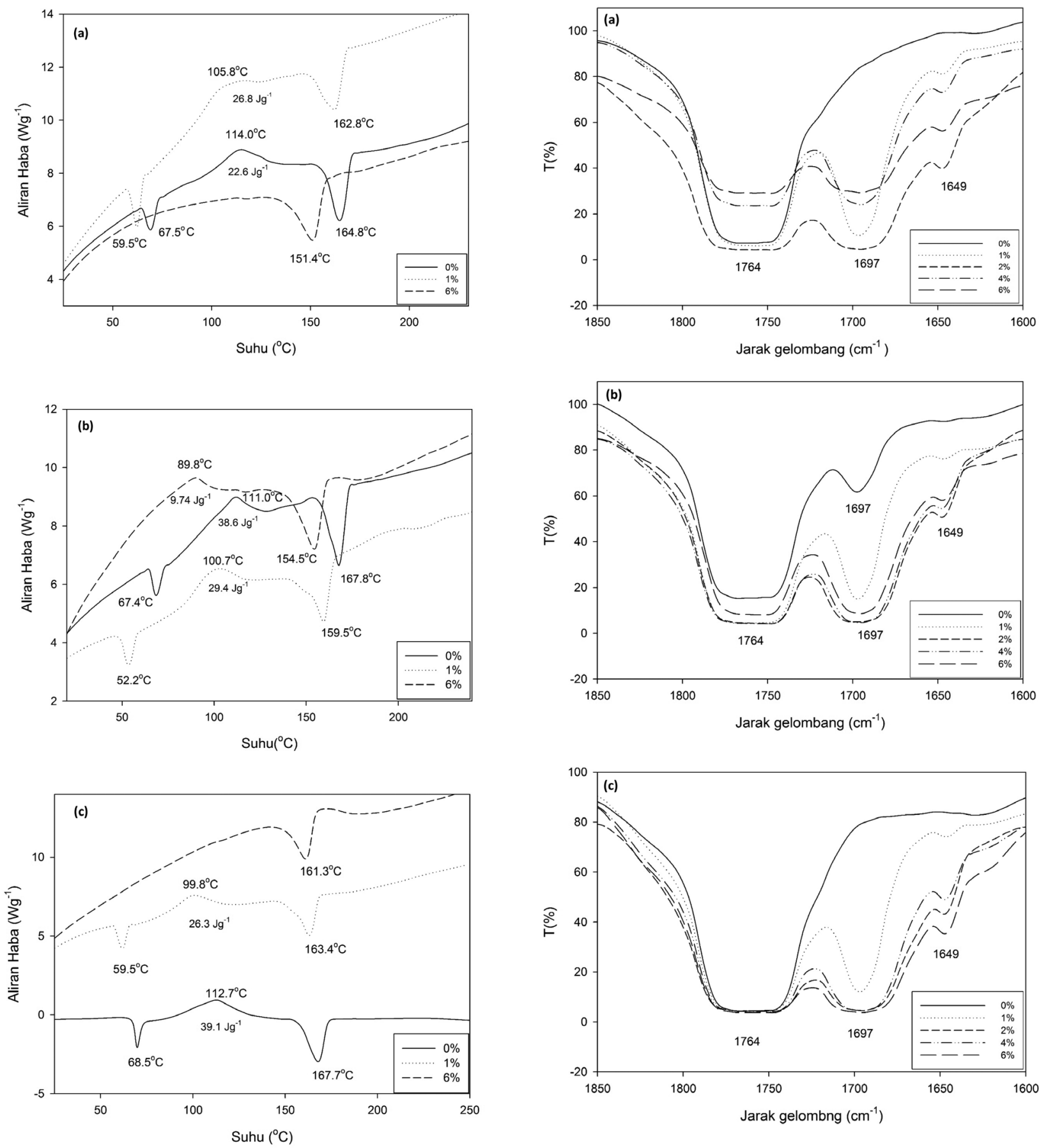

RAJAH 2. Lengkung termogram DSC bagi sampel (a) PLLA tidak diiradiasi (b) iradiasi elektron dan c) iradiasi $\gamma$

on the structure, thermal resistance and mechanical properties of the PLA/EVOH blends. Nuclear Instruments and Methods in Physics Research Section B: Beam Interactions with Materials and Atoms 274: 139-144.

Loo, S.C.J., Ooi, C.P. \& Boey, Y.C.F. 2004. Radiation effects on poly(lactide-co-glycolide) (PLGA) and poly(l-lactide) (PLLA). Polymer Degradation and Stability 83: 259-265.

Lou, T., Wang, X., Song, G., Gu, Z. \& Yang, Z. 2014. Fabrication

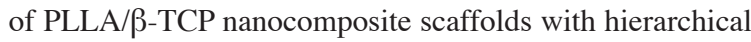
porosity for bone tissue engineering. International Journal of Biological Macromolecules 69: 464-470.

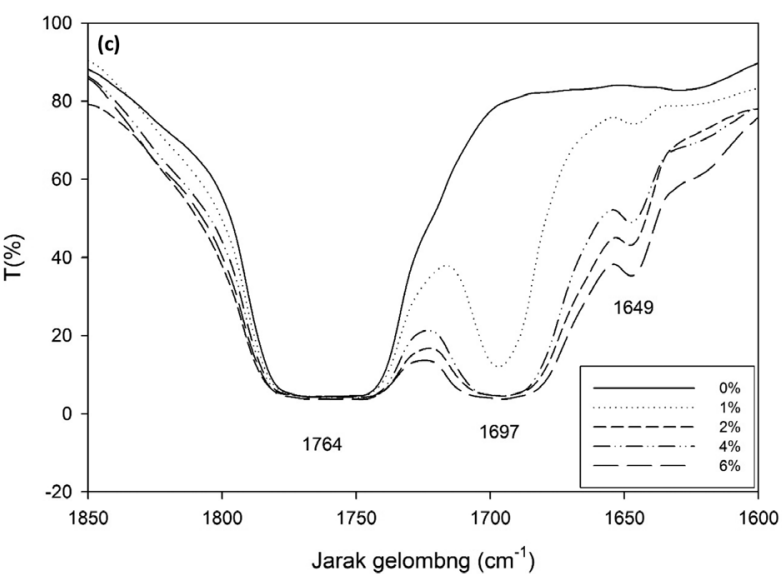

RAJAH 3. Spektra FTIR bagi sampel PLLA (a) tidak diiradiasi, (b) iradiasi elektron dan (c) iradiasi gamma dengan pelbagai kandungan TIAC

Malinowski, R. 2016. Effect of high energy $\beta$-radiation and addition of triallyl isocyanurate on the selected properties of polylactide. Nuclear Instruments and Methods in Physics Research Section B: Beam Interactions with Materials and Atoms 377: 59-66.

Malinowski, R., Rytlewski, P., Janczak, K., RaszkowskaKaczor, A., Moraczewski, K., Stepczyńska, M. \& Żuk, T. 2015. Studies on functional properties of PCL films modified by electron radiation and TAIC additive. Polymer Testing 48: 169-174. 
Mat Uzir, W.,Azman, H., Akos, N.I., Nurhayati,A.Z. \& Kayathre, K. 2015. Mechanical, thermal and chemical resistance of epoxidized natural rubber toughened polylactic acid blends. Sains Malaysiana 44: 1615-1623.

Milicevic, D., Milivojevic, D. \& Suljovrujic, E. 2012. The influence of the initial preparation and crystallinity on the free radical evolution in gamma irradiated PLLA. Radiation Physics and Chemistry 81: 1361-1365.

Milicevic, D., Trifunovic, S., Dojcilovic, J., Ignjatovic, N. \& Suljovrujic, E. 2010. The influence of gamma radiation on the molecular weight and glass transition of PLLA and HAp/ PLLA nanocomposite. Nuclear Instruments and Methods in Physics Research Section B: Beam Interactions with Materials and Atoms 268: 2744-2749.

Nagasawa, N., Kaneda, A., Kanazawa, S., Yagi, T., Mitomo, H., Yoshii,F. \& Tamada, M. 2005.Application of poly(lactic acid) modified by radiation crosslinking. Nuclear Instruments and Methods in Physics Research Section B: Beam Interactions with Materials and Atoms 236: 611-616.

Nur Aimi, M.N., Anuar, H., Maizirwan, M., Sapuan, S.M., Wahit, M.U. \& Zakaria, S. 2015. Preparation of durian skin nanofibre (DSNF) and its effect on the properties of polylactic acid (PLA) biocomposites. Sains Malaysiana 44: 1551-1559.

Quynh, T.M., Mitomo, H., Nagasawa, N., Wada, Y., Yoshii, F. \& Tamada, M. 2007. Properties of crosslinked polylactides (PLLA \& PDLA) by radiation and its biodegradability. European Polymer Journal 43: 1779-1785.

Raghu, S., Archana, K., Sharanappa, C., Ganesh, S. \& Devendrappa, H. 2016. Electron beam and gamma ray irradiated polymer electrolyte films: Dielectric properties. Journal of Radiation Research and Applied Sciences 9: 117-124.

Rodenas-Rochina, J., Vidaurre, A., Castilla Cortázar, I. \& Lebourg M. 2015. Effects of hydroxyapatite filler on longterm hydrolytic degradation of PLLA/PCL porous scaffolds. Polymer Degradation and Stability 119: 121-131.

Rytlewski, P., Malinowski, R., Moraczewski, K. \& Żenkiewicz, M. 2010. Influence of some crosslinking agents on thermal and mechanical properties of electron beam irradiated polylactide. Radiation Physics and Chemistry 79: 1052-1057.
Said, H.M. 2013. Effects of gamma irradiation on the crystallization, thermal and mechanical properties of poly(1lactic acid)/ethylene-co-vinyl acetate blends. Journal of Radiation Research and Applied Sciences 6: 11-20.

Suljovrujić, E., Ignjatović, N., Uskoković, D., Mitrić, M., Mitrović, M. \& Tomić, S. 2007. Radiation-induced degradation of hydroxyapatite/poly L-lactide composite biomaterial. Radiation Physics and Chemistry 76: 722-728.

Yang, S.1., Wu, Z.H., Yang, W. \& Yang, M.B. 2008. Thermal and mechanical properties of chemical crosslinked polylactide (PLA). Polymer Testing 27: 957-963.

Zhang, X., Kotaki, M., Okubayashi, S. \& Sukigara, S. 2010. Effect of electron beam irradiation on the structure and properties of electrospun PLLA and PLLA/PDLA blend nanofibers. Acta Biomaterialia 6: 123-129.

Mohd Reusmaazran bin Yusof, Yusof Abdullah \&

Norzita bt Yaacob

Kumpulan Teknologi Bahan

Agensi Nuklear Malaysia, Bangi

43000 Kajang, Selangor Darul Ehsan

Malaysia

Roslinda Shamsuddin*

Program Sains Bahan, Pusat Pengajian Fizik Gunaan

Fakulti Sains dan Teknologi

Universiti Kebangsaan Malaysia

43600 Bangi, Selangor Darul Ehsan

Malaysia

*Pengarang untuk surat-menyurat; email: linda@ukm.edu.my

Diserahkan: 21 Jun 2016

Diterima: 19 Oktober 2016 